\title{
Comparative evaluation of traditional and improved cultivation practices and cultivars of Colocasia esculenta (L.) H. W. Schott in the Borail Hills Range of India
}

\author{
Pramod Medhi ${ }^{* 1}$, Aniruddha Sarma ${ }^{2} \&$ Harish G D ${ }^{3}$ \\ ${ }^{1}$ Department of Botany, Pandu College, Guwahati 781 012, India \\ ${ }^{2}$ Department of Biotechnology, Pandu College, Guwahati 781 012, India \\ ${ }^{3}$ ICAR-NBPGR Regional Station, Shillong 793 103, India \\ *Email: pramodmedhi29@gmail.com
}

\section{ARTICLE HISTORY}

Received: 04 March 2021

Accepted: 21 July 2021

Available online

Version 1: 22 August 2021

Version 2: 16 October 2021

Version 3: 05 February 2022

\section{KEYWORDS}

Edible Colocasia esculenta Traditional versus improved

Cultivation practice

Tuber yield evaluation

\begin{abstract}
Present work was focused on the comparative evaluation of the Taro tuber productivity by using improved cultivation practices versus traditional cultivation practices. Initially, passport data of all the collected 27 cultivars and wild edible aroids were prepared and their Indigenous Collection Numbers (IC) were procured from the Indian Council of Agricultural Research-National Bureau of Plant Genetic Resources, New Delhi. All the collections were phytochemically evaluated and five variants of Colocasia esculenta (L.) H. W. Schott were found to be superior and their IC Numbers are 0631527, 0631529, 0631536, 0631544 and 0631546. Following the randomised block design method for crop productivity evaluation, data of five nutritionally superior cultivar and one check variety were taken in three replications (R1, R2, R3) from eighteen plots of measuring $5 \times 5 \mathrm{~m}^{2}\left(25 \mathrm{~m}^{2}\right)$. Taro tuber productivity in $\mathrm{kg} /$ plant from the first and second year's data from the ICAR-NBPGR, Umiam and also the farmer's data from Borail Hills Range were analysed by using SPSS software, and that shows significant difference among all the six treatments/variants under Critical Difference at 5\% (CD 5\%). Total of the data replications (R1+R2+R3) from first, second year data from ICAR-NBPGR, Umiam and also farmer's data from Borail Hills Range are $18.24 \mathrm{~kg}, 19.45 \mathrm{~kg}$ and $12.69 \mathrm{~kg}$ respectively; clearly showing the tuber productivity enhancement of improved cultivation practices over the traditional agro- practices.
\end{abstract}

\section{Introduction}

Colocasia esculenta (L.) H. W. Schott belongs to the family Araceae, commonly known as Taro. Taro is grown throughout the tropics and in a few parts of subtropics. It is a highly polymorphic species with wide morphological variability. There are two types of Taro-the Dasheen type and the Eddoe type. The Dasheen type is $C$. esculenta var. esculenta and the Eddoe type is $C$. esculenta var. antiquorum. The Dasheen type has a large main corm with 2-3 cormels. The sterile appendage of the spadix is short. Generally, the group has 28 chromosomes (1). The Eddoe type has a small or medium corm which is not edible with 5-20 cormels. The sterile appendage of the spadix is larger than the male portion and three times more than that of Dasheen. This group has 42 chromosomes (1).

The Borail Hills Range of Assam lies between $24^{\circ}$ $58^{\prime} \mathrm{N}$ to $25^{\circ} 50^{\prime} \mathrm{N}$ latitudes and $92^{\circ} 50^{\prime} \mathrm{E}$ to $92^{\circ} 52^{\prime} \mathrm{E}$ longitudes. Due to poor road connectivity to the Borail
Hill Range of Assam, the inhabitant ethnic groups have been dependent mainly on Jhum cultivation and the forests for their food, medicine etc. The main ethnic groups of the area are the Dimasas, Zeme Nagas, Hmars, Hrangkhols, Biates, Kukis, Sakacheps, Vaipheis and Pnars.

The major food grain rice produced in Jhum is limited and one season's production cannot meet the needs of the households for the whole year. When the rice stock decreases, they start mixing rice with the Aroids and other tubers as a supplementary diet. Due to the high starch content with good calorie value, tubers have a major role in meeting the food security of the ethnic people of the area. The tubers are mostly used as vegetable/curry or as subsidiary food for an alternative carbohydrate source after roasting, baking, or boiling. The leaves are also consumed as vegetable. Tubers are rich source of Calcium, Iron, Phosphorus, Zinc, Vitamin A and Vitamin C. As the tribal groups

C Medhi et al (2021). This is an open-access article distributed under the terms of the Creative Commons Attribution License, which permits unrestricted use, distribution and reproduction in any medium, provided the original author and source are credited (https://creativecommons.org/licenses/by/4.0/). 
cultivate the edible aroids in the homestead area and in and around the vicinity of their villages and also sparingly in the Jhum lands. It is presumed that the development of an improved cultivation practice/agro-technique is needed for increasing tuber production. This will ensure the enhanced productivity and food security of the tribal groups. Additional income generation by selling their agroproducts, including tubers and fresh and dried Taro leaves, is another income source for those ethnic groups (2).

ICAR-CTCRI, Thiruvananthapuram, India, developed clear guidelines for large scale commercial Taro cultivation. However, the agro-technique developed was mainly suitable for lowland and valleys. Emphasis was mainly given to select better planting material, land preparation and method of planting, mulching technique, manuring and weeding, crop protection and harvesting (3), which is mainly cultivated in Eastern and Southern States of India. Most of these edible Colocasia species is also sparingly cultivated in the valleys and hills of the North-Eastern parts of India. Some of the lowland Taro variants are cultivated in the plains and valleys and upland Taro variants in the hilly terrains of the region.

With this backdrop, an attempt was made to develop an improved cultivation practice with local need-based modifications for upland farmers of North East India. At the same time, there was a comparative evaluation of crop production from the improved cultivation practices with the traditional cultivation practices of the nutritionally superior Taro accessions. Delivering the improved cultivation package of practice to hill farmers was also an important part of the present work. Taro has been studied in different parts of the world, including India, covering different aspects. Some of the references came across during perusal of literature on taxonomic studies $(2,4,5,8,9)$, genetic variation (6-9), traditional knowledge on aroids $(10,11)$, crop improvement (12-20), Taro cultivation practices (2130), aroid tuber crop harvest (31) and crop productivity evaluation $(32,33)$.

\section{Materials and Methods}

\section{Sample collection, taxonomic identification and field characterisation}

Individual sampling was done selectively for collecting all the 27 cultivars and wild edible aroid germplasm samples in the form of tubers since September 2016 to February 2017 and identified the plant samples considering morphological characters by using standard literature $(4,5)$. In addition, passport information data and also field characterisation on each accession was recorded at the time of collection, following the standard procedure of the National Bureau of Plant Genetic Resource (ICAR-NBPGR) (34).

All the collected aroid germplasm were submitted to ICAR-NBPGR Shillong Regional Station, India, for further conservation and multiplication.
Later Indigenous Collection (IC) numbers of each of the accessions were obtained from National Authority (ICAR-NBPGR, New Delhi).

\section{Sample preparation and phytochemical analysis}

Taro tubers i.e.corms or cormels were cleaned with water, thin-sliced, and air-dried. Care was taken by regular flipping of the thin tuber slices and allowed to be air-dried to avoid fungus contamination. Then the samples were dried in a hot air oven at $60^{\circ} \mathrm{C}$ till a constant weight was obtained. Finally, the dried materials were ground to powder and stored at $4{ }^{\circ} \mathrm{C}$ for further analysis. Phytochemical analysis of the prepared tuber powders was carried out in a moisture-free environment in the laboratory.

Estimation of the nutritional properties included total carbohydrate estimation done by following standard procedure Anthrone's method (35) and protein by Lowry's method (36), total fat estimated by using Soxhlet apparatus (Soxhlet method), total crude fibre contents estimated by extracting fibres and expressed as percentage of the original defatted sample (37), and calorific value by using a Bomb calorimeter (Make: Optics Tech). Nutraceutical properties estimation includes total mineral content by Gravimetric method using Miffle furnace (Make: Optics Tech), total phenolic content by FolinCiocalteau's method (38), antioxidant activity by standard radical scavenging effect of stable DPPH method (39), ascorbic acid by using 2, 6- dichloro phenol indophenol dye (40) and the flavonoid content by spectroscopic (Make: Cystronics 2020) analysis (41).

The standard permissible limit of the oxalate contents in edible aroids is $71 \mathrm{mg} / 100 \mathrm{gm}$, and beyond this limit is not recommended for human consumption. Estimation of antinutritional properties (oxalates/ ammonium oxalates) was done by titration method (42).

Quantification of microelement in the selected superior Taro samples wasdone viz. Ca, Fe and $\mathrm{Zn}$ by Atomic Absorption Spectrophotometer (Model: AAS700, Perkin Elmer). Standard methodology (43, 44), was followed for the digestion and analytical procedures for the quantification of total metal concentration in dried sample powders.

\section{Selection of superior Taro germplasm}

As the tubers are a reservoir of energy or nutrition and therefore, during the selection of superior cultivar germplasm, emphasis was mainly given to the higher calorific value and low antinutritional properties like oxalates/ammonium oxalates of the tubers or cormels studied. Higher value of total crude fibre, total mineral contents were also taken into consideration for selection of superior Taro accessions. Higher value of the nutraceutical properties i.e. total phenolic content, antioxidant activity, ascorbic acid, flavonoid content were also considered but plays less significant role for selection of superior Taro tubers as these are rich in energy/calorific value. Quantification of microelement was done only in the selected five superior Taro accessions. 


\section{Improved cultivation practice (Agro-technique) for upland Taro}

During the field trial, few notable modifications were made for upland cultivation in the hilly terrains of Borail Hill Range. The use of chemical fertilisers and fungicides/pesticides were avoided for the interest of economically backward hill-dwelling farmers. So, vermicompost and neem seed extracts were used as endogenous resources for the sustainable and organic hill farming practices.

Distinctly, the following are the few important points emphasised during the field trial in the case of improved cultivation practices for upland cultivation of Taro, which was not recorded so far to be practised traditionally in the Borail Hill Range earlier.

1. Taro grows well in warm and humid conditions with mean temperatures ranging from $21-27^{\circ} \mathrm{C}$ and rainfall of $1000 \mathrm{~mm}$ or above. Taro can be cultivated in all soil types but produces better tuber in well-drained fertile loamy soils. So, the North-eastern hills are a suitable agro-climate for upland Taro cultivation [3]. Agroclimatically, under rainfed conditions in the hills of North East India, traditionally planting is done during April to June, and the same is recommended.

2. Selection of healthy cormels and the corms were given emphasis to be used as planting material.

3. The pit method or raised bed method of land preparation can be adopted. In sandy loam soils in Umrangsho area, the pit method is preferred, whereas, in alluvial soils, raised mounds or beds are better.

4. Mulching helps early sprouting, control growing weeds, regulates soil temperature and also retain soil moisture. The planted seed tubers recommended being mulched with green or dry leaves/straw from the nearby forest or jhum land.

5. Traditional Hill Agricultural System in Northeastern India is an organic one. So, no chemical fertiliser application will be suitable to recommend in the region from both cultural and environmental points of view. So, the application of 10-12 tons of Farm Yard Manure (FYM) per hectare and mixing it with soil before planting is recommended. The use of vermicompost is also another option for soil fertility enhancement.

6. For controlling aphids and worms locally, the following are some of the useful measures:
a. Use of healthy planting materials
b. Early planting to avoid heavy monsoon rains
c. Removal of self-grown Colocasia plants
d. Neem seed extracts to be used to repel insect pests

7. Weeding and earthing-up operations are essential as per planting protocol, but performing manual weeding is already a common practice among hill farmers.

8. After 6-8 months from planting, harvesting is done by carefully uprooting the plants along with corms and cormels and then separated for consumption and further use as planting material.

\section{Field trials}

An improved cultivation practice of the selected superior Taro cultivars for upland cultivation has been done by following the standard guidelines of Central Tuber Crop Research Institute (CTCRI), Thiruvananthapuram, India, with slight modifications as per local needs of the upland areas. CTCRI mainly developed it for valleys and lowland areas. However, clearly, in the present work, emphasis was given to the rain-fed upland and hilly terrains of North East India, including Borail Hills Range.

Two years of field trials using improved cultivation practice was conducted during the month of May to November in the year 2017 and 2018 at ICAR-NBPGR, Umiam for evaluation of Taro tuber productivity. Only the Nutritionally superior selected five cultivar variants were cultivated in the trial station for tuber productivity evaluation. Following the randomised block design method for crop productivity evaluation, data of five nutritionally superior cultivar and one check variety were taken in three replications (R1, R2, R3) from total 18 plots of each one measuring $5 \times 5 \mathrm{~m}^{2}\left(25 \mathrm{~m}^{2}\right)$. Altitude and soil types of the ICAR-NBPGR, Umiam field trial station were similar to the cultivable lands of Borail Hills Range.Thus, the farmers field of the Borail Hills Range and the field trial station of ICAR-NBPGR, Umiam are agro-climatically similar under the North East Indian region.

Similarly, farmers from Borail Hills Range were also engaged for evaluation of Taro tuber productivity during the month of May to November in the year 2017. Traditional cultivation process was followed strictly by the farmers in the Jhum fields of the hilly terrain. Regular weeding, earthing up, mulching were not done and also use of manures and organic pesticides were not practiced in the traditional cultivation practices, in general. During field trial, tuber productivity data were recorded in three replications by using same randomised block design method applied as in ICAR-NBPGR, Umiam trial station.

In both the field trial locations, i.e. ICAR-NBPGR, Umiam and Borail Hills Range, a sixth high yielding cultivar variety $C$. esculenta var. esculenta (CultivarPanchamukhi), collected from local market was used as check variety for comparing the critical/significant difference in tuber productivity with the nutritionally superior five cultivar variants/treatments. So, there are total six treatments/variants were cultivated and also total 18 standard plots/observations were adopted during field trials for both the improved and traditional methods of cultivation. Tuber productivity was considered in $\mathrm{kg}$ plant. Thus, clearly tuber productivity data were obtained for a comparative 
evaluation between the improved and the traditional method of cultivation practices.

\section{Statistical analysis}

For statistical analysis Statistical Package for the Social Sciences (SPSS) software on Windows operating system platform was used. Total six treatments that includes five nutritionally superior Colocasia cultivars (T1-IC0631527, T2- IC0631529, T3IC0631536, T4-IC0631544, T5-IC-0631546) and one check variety $C$. esculenta var. esculenta (CultivarPanchamukhi) were considered. All the data were taken in three replications (i.e. Replication-R1, R2, R3) from each treatment/ Colocasia variants. Clearly, a total of 18 observations (i.e. 6 treatments $\mathrm{x} 3$ replications each) were used for tuber productivity data analysis.

\section{Results and Discussion}

Field collection of total 27 aroids from Boraih Hills Range was successfully done during September 2016 to February 2017. During the collection of samples, were characterised carefully by recording the important features of the collected tuber germplasms. Field characterization of the selected nutritionally superior Taro variants has been listed carefully. Additionally, the starch content in terms of percentage was also recorded after phytochemical estimation (Table 1).
Ammonium Oxalates were found to be ranging from $56.78 \pm 0.02$ to $62.73 \pm 0.19 \mathrm{mg} / 100 \mathrm{gm}$, which are below the standard permissible limit of $71 \mathrm{mg} / 100 \mathrm{gm}$ for human consumption (Table 2).

\section{Comparative evaluation crop productivity: Traditional vs improved cultivation process}

During field trial from ICAR-NBPGR, Umiam and the farmers of Borail Hills Range, there were six treatments/ Colocasia variants and three replications (R1, R2, R3) for each treatments. Thus, two years randomised block design cultivation trials from ICARNBPGR, Umiam trial station and one year from Borail Hills Range were consideded. There were total 18 cultivation blocks and observations in total for the six treatments/cultivars and the tuber productivity in kilogram per plant.

Taro tuber productivity from the first year's data analysis using SPSS software from the ICARNBPGR, Umiam shows significant difference in productivity between the check variant (CultivarPanchamukhi) with the six treatments/Colocasia variants each, under Critical Difference at 5\% ( CD $=0.28$ ). Again, there is also a significant difference among all the six treatments /Colocasia variants (Table 3). Similarly, second year's data analysis from the field trials of ICAR-NBPGR, Umiam also shows significant difference in productivity under CD (5\%)=0.31 (Table 4).

Table 1. Field characterisation of the nutritionally superior Taro cultivars.

\begin{tabular}{|c|c|c|}
\hline Botanical name; Coll. No./IC no. & Vern. name & Field characters/Special features \\
\hline $\begin{array}{l}\text { Colocasia esculenta (L.) H.W. Schott } \\
\text { cv. Panchamukhi } \\
\text { (Dasheen type). PM- GDH- } \\
1187 / 0631527\end{array}$ & $\begin{array}{l}\text { Bahnar -tam }(\mathrm{Hm} / \mathrm{Mi}) \\
\text { Thakhlong }(\mathrm{Di})\end{array}$ & $\begin{array}{l}\text { Leaf and petiole pale green, corm and cormels are non acrid; Large tuber } \\
\text { with predominant } 3-5 \text { lateral buds; Good cooking quality and taste; Starch } \\
\text { content } 63.10 \% \text { and protein } 2.45 \% \text {. }\end{array}$ \\
\hline $\begin{array}{l}\text { Colocasia esculenta var. antiquorum } \\
\text { (L.) H.W. Schott } \\
\text { (Eddoe type). PM- GDH-1189/0631529 }\end{array}$ & $\begin{array}{l}\text { Rawsen }(\mathrm{Hm}) ; \text { Thadisa- } \\
\text { gajao }(\mathrm{Di})\end{array}$ & $\begin{array}{l}\text { Leaf, petiole, corm and cormels are non acrid; Number of cormels 5-20 with } \\
\text { reddish apical cormel buds; Good cooking quality and taste; Starch content } \\
47.21 \% \text { and protein } 3.28 \% \text {. }\end{array}$ \\
\hline $\begin{array}{l}\text { Colocasia esculenta var. esculenta (L.) } \\
\text { H.W. Schott } \\
\text { (Dasheen type). PM- GDH- } \\
1196 / 0631536\end{array}$ & $\begin{array}{c}\text { Manjang (Hr); Thahon } \\
\text { (Di) }\end{array}$ & $\begin{array}{l}\text { Leaf, petiole, corm and cormels are non acrid. Dark green leaf and petiole; } \\
\text { Leaf petiole and corm preferred for edible purpose; Rounded corm with 5- } \\
20 \text { cormels; Good cooking quality and taste; Starch content } 64.93 \% \text { and } \\
\text { protein } 3.67 \% \text {. }\end{array}$ \\
\hline $\begin{array}{l}\text { Colocasia esculenta var. esculenta (L.) } \\
\text { H.W. Schott } \\
\text { (Dasheen type). PM- GDH- } \\
1353 / 0631544\end{array}$ & Hen-then-tut (Ka) & $\begin{array}{l}\text { Leaf, petiole, corm and cormels are non acrid; Elongated corm mainly lies } \\
\text { above the soil surface; Elongated corm with tapering apex and upto } 4 \\
\text { cormels; Good cooking quality and taste; Starch content } 45.46 \% \text { and } \\
\text { protein } 3.67 \% \text {. }\end{array}$ \\
\hline $\begin{array}{l}\text { Colocasia esculenta var. esculenta (L.) } \\
\text { H.W. Schott } \\
\text { (Dasheen type). PM- GDH- } \\
1355 / 0631546\end{array}$ & Hon-phangwo-tar $(\mathrm{Ka})$ & $\begin{array}{l}\text { Leaf, petiole, corm and cormels are non acrid; Large } 4-5 \text { cormels arise from } \\
\text { the base of the main tuber; Elongated cormels are very prominent with } \\
\text { tapering apex; Good cooking quality and taste; Starch content } 40.6 \% \text { and } \\
\text { protein } 3.11 \% \text {. }\end{array}$ \\
\hline
\end{tabular}

Out of 27 cultivar and wild edible aroids estimated phytochemically, five $C$. esculenta variants are found to be nutritionally and nutraceutically superior (i.e. IC-0631527, 0631529, 0631536, 0631544 and 0631546). These were selected and sorted out from the rest of the cultivars for field trials and standardisation of improved cultivation practices for upland cultivation. During the selection of superior germplasm, apart from the nutraceutical properties, emphasis was mainly given to the higher calorific value and less anti-nutritional properties like oxalates/ammonium oxalates. Calorific value in the selected superior Taro variants ranging from $357.78 \pm 0,04$ to $365.10 \pm 0.21 \mathrm{mg} / 100 \mathrm{gm}$. Antinutritional properties in the form of Oxalates/
Again, during the cropping season from May to November 2017, Taro productivity data from the field trial of the farmers of Borail Hills Range, India also shows a significant difference in productivity among the treatments/ Colocasia variants under CD $(5 \%)=0.20$ (Table 5).

Total of the data replications (R1+R2+R3) from first, second year data from ICAR-NBPGR, Umiam and also farmer's data from Borail Hills Range are 18.24 $\mathrm{kg}, 19.45 \mathrm{~kg}$ and $12.69 \mathrm{~kg}$ respectively. It also, clearly shows the tuber productivity has significantly enhanced after using improved upland Taro cultivation practices in comparision to the traditional Taro cultivation practices. 
Table 2. List of selected nutritionally superior Taro cultivars based on phytochemical analysis.

\begin{tabular}{|c|c|c|c|c|c|c|c|c|c|c|c|c|c|c|}
\hline \multirow{2}{*}{$\begin{array}{l}\text { Collection } \\
\text { no./ } \\
\text { IC no. }\end{array}$} & \multirow{2}{*}{$\begin{array}{l}\text { Carbohy- } \\
\text { drate }(\%)\end{array}$} & \multirow{2}{*}{$\begin{array}{l}\text { Protein } \\
\text { (\%) }\end{array}$} & \multirow{2}{*}{$\begin{array}{l}\text { Total } \\
\text { fat }(\%)\end{array}$} & \multirow{2}{*}{$\begin{array}{l}\text { Total } \\
\text { crude } \\
\text { fibre(\%) }\end{array}$} & \multirow{2}{*}{$\begin{array}{l}\text { Total } \\
\text { mineral } \\
(\%)\end{array}$} & \multirow{2}{*}{$\begin{array}{l}\text { Ascorbic } \\
\text { acid } \\
\text { (mg/100 } \\
\text { gm) }\end{array}$} & \multirow{2}{*}{$\begin{array}{l}\text { Total } \\
\text { phenolic } \\
\text { content } \\
\text { ( } \mu \text { gGAE/ } \\
\text { mg }\end{array}$} & \multirow{2}{*}{$\begin{array}{l}\text { Antioxid- } \\
\text { ant } \\
\text { Activity } \\
\text { IC50 } \\
(\mu \mathrm{g} / \mathrm{ml})\end{array}$} & \multirow{2}{*}{$\begin{array}{l}\text { Flavon- } \\
\text { oid } \\
\text { ( } \mu \mathrm{Gqe} / \\
\text { mg) }\end{array}$} & \multirow{2}{*}{$\begin{array}{l}\text { Caloific } \\
\text { value } \\
\text { (kcal/ } \\
100 \text { gm) }\end{array}$} & \multirow{2}{*}{$\begin{array}{l}\text { Oxalates/ } \\
\text { Ammonium } \\
\text { Oxalates } \\
\text { (mg/100 } \\
\text { gm) }\end{array}$} & \multicolumn{3}{|c|}{$\begin{array}{l}\text { Micronutrient } \\
\text { Content } \\
\text { (mg/100 gm) }\end{array}$} \\
\hline & & & & & & & & & & & & Zn & $\mathrm{Ca}$ & $\mathbf{F e}$ \\
\hline $\begin{array}{l}\text { PM- GDH- } \\
1187 \\
\text { /0631527 } \\
\end{array}$ & $\begin{array}{l}63.10 \\
\pm 0.24\end{array}$ & $\begin{array}{c}2.45 \\
\pm 0.02\end{array}$ & $\begin{array}{c}2.35 \\
\pm 0.07\end{array}$ & $\begin{array}{c}2.15 \\
\pm 0.61\end{array}$ & $\begin{array}{c}4.72 \\
\pm 0.03\end{array}$ & $\begin{array}{l}30.83 \\
\pm 0.39\end{array}$ & $\begin{array}{l}25.32 \\
\pm 0.10\end{array}$ & $\begin{array}{c}145.73 \\
\pm 0.16\end{array}$ & $\begin{array}{c}8.43 \\
\pm 0.03\end{array}$ & $\begin{array}{c}365.10 \pm \\
0.21\end{array}$ & $61.89 \pm 0.10$ & 5.83 & 153.98 & 6.60 \\
\hline $\begin{array}{l}\text { PM- GDH- } \\
1189 \\
\text { /0631529 } \\
\end{array}$ & $\begin{array}{l}47.21 \\
\pm 0.21\end{array}$ & $\begin{array}{c}3.28 \\
\pm 0.04\end{array}$ & $\begin{array}{c}2.27 \\
\pm 0.22\end{array}$ & $\begin{array}{c}4.25 \\
\pm 0.12\end{array}$ & $\begin{array}{l}3.05 \\
\pm 0.1\end{array}$ & $\begin{array}{l}29.43 \\
\pm 0.06\end{array}$ & $\begin{array}{l}18.34 \\
\pm 0.13\end{array}$ & $\begin{array}{c}112.53 \\
\pm 1.03\end{array}$ & $\begin{array}{c}6.26 \\
\pm 0.17\end{array}$ & $\begin{array}{c}361.82 \pm \\
0.05\end{array}$ & $57.52 \pm 0.05$ & 9.07 & 202.85 & 1.81 \\
\hline $\begin{array}{l}\text { PM- GDH- } \\
1196 \\
\text { /0631536 } \\
\end{array}$ & $\begin{array}{l}64.93 \\
\pm 0.01\end{array}$ & $\begin{array}{c}2.77 \\
\pm 0.03\end{array}$ & $\begin{array}{c}0.49 \\
\pm 0.08\end{array}$ & $\begin{array}{c}2.5 \\
\pm 0.23\end{array}$ & $\begin{array}{c}1.72 \\
\pm 0.11\end{array}$ & $\begin{array}{l}27.02 \\
\pm 0.04\end{array}$ & $\begin{array}{l}24.53 \\
\pm 0.02\end{array}$ & $\begin{array}{c}107.32 \\
\pm 0.11\end{array}$ & $\begin{array}{c}8.48 \\
\pm 0.10\end{array}$ & $\begin{array}{c}360.74 \pm \\
0.06\end{array}$ & $61.17 \pm 0.04$ & 34.12 & 36.21 & 38.12 \\
\hline $\begin{array}{l}\text { PM- GDH- } \\
1353 \\
\text { /0631544 } \\
\end{array}$ & $\begin{array}{l}45.46 \\
\pm 0.08\end{array}$ & $\begin{array}{c}3.67 \\
\pm 0.14\end{array}$ & $\begin{array}{c}2.45 \\
\pm 0.17\end{array}$ & $\begin{array}{c}4.76 \\
\pm 0.56\end{array}$ & $\begin{array}{c}5.80 \\
\pm 0.12\end{array}$ & $\begin{array}{l}28.56 \\
\pm 0.25\end{array}$ & $\begin{array}{l}20.04 \\
\pm 0.10\end{array}$ & $\begin{array}{c}136.90 \\
\pm 0.11\end{array}$ & $\begin{array}{c}8.40 \\
\pm 0.02\end{array}$ & $\begin{array}{c}359.49 \pm \\
0.02\end{array}$ & $62.73 \pm 0.19$ & 5.32 & 61.10 & 8.87 \\
\hline $\begin{array}{l}\text { PM- GDH- } \\
1355 \\
\text { /0631546 } \\
\end{array}$ & $\begin{array}{c}40.6 \\
\pm 0.76\end{array}$ & $\begin{array}{c}3.11 \\
\pm 0.03\end{array}$ & $\begin{array}{c}1.56 \\
\pm 0.04\end{array}$ & $\begin{array}{c}4.89 \\
\pm 0.03\end{array}$ & $\begin{array}{c}6.30 \\
\pm 0.23\end{array}$ & $\begin{array}{l}38.56 \\
\pm 0.04\end{array}$ & $\begin{array}{l}27.32 \\
\pm 0.05\end{array}$ & $\begin{array}{c}143.54 \\
\pm 0.76\end{array}$ & $\begin{array}{c}7.38 \\
\pm 0.42\end{array}$ & $\begin{array}{c}357.78 \pm \\
0,04\end{array}$ & $56.78 \pm 0.02$ & 4.72 & 102.77 & 10.49 \\
\hline
\end{tabular}

Table 3. First year's (May-November 2017) Taro productivity data analysis from the field trial of ICAR-NBPGR, Umiam.

\begin{tabular}{lrrrrrr}
\hline \multicolumn{1}{c}{ No of parent/treatment/ genotypes } & \multicolumn{1}{c}{ R1 } & \multicolumn{1}{c}{ R2 } & \multicolumn{1}{c}{ R3 } & \multicolumn{1}{c}{ Total } & Mean \pm SD & \multicolumn{1}{c}{ Mean \pm SE } \\
\hline T1-IC0631527 & 0.89 & 0.96 & 0.92 & 2.77 & $0.923 \pm 0.03512$ & $0.923 \pm 0.020276$ \\
\hline T2- IC0631529 & 1 & 1.2 & 0.9 & 3.1 & $1.03 \pm 0.152753$ & $1.03 \pm 0.088192$ \\
\hline T3-IC0631536 & 0.76 & 0.72 & 0.79 & 2.27 & $0.757 \pm 0.03512$ & $0.757 \pm 0.020276$ \\
\hline T4-IC0631544 & 0.9 & 0.7 & 0.8 & 2.4 & $0.800 \pm 0.10$ & $0.800 \pm 0.057735$ \\
\hline T5-IC-0631546 & 0.8 & 0.65 & 0.75 & 2.2 & $0.733 \pm 0.076376$ & $0.733 \pm 0.044096$ \\
\hline $\begin{array}{l}\text { C. } \text { esculenta } \text { var. esculenta } \\
\text { (Cultivar-Panchamukhi) }\end{array}$ & 1.5 & 2 & 2 & 5.5 & $1.83 \pm 0.288675$ & $1.83 \pm 0.166667$ \\
\hline
\end{tabular}

*CD $(5 \%)=0.28$

Table 4. Second year's (May-November 2018) Taro productivity data analysis from the field trial of ICAR-NBPGR, Umiam.

\begin{tabular}{lrrrrrr}
\hline \multicolumn{1}{c}{ No of parent/treatment/ genotypes } & \multicolumn{1}{c}{ R1 } & \multicolumn{1}{c}{ R2 } & \multicolumn{1}{c}{ R3 } & \multicolumn{1}{l}{ Total } & \multicolumn{1}{c}{ Mean \pm SD } & \multicolumn{1}{c}{ Mean \pm SE } \\
\hline T1-IC0631527 & 0.91 & 0.76 & 0.72 & 2.39 & $0.797 \pm 0.100167$ & $0.797 \pm 0.057831$ \\
\hline T2- IC0631529 & 1.19 & 1.39 & 1.09 & 3.67 & $1.22 \pm 0.152753$ & $1.22 \pm 0.088192$ \\
\hline T3-IC0631536 & 0.62 & 0.67 & 0.72 & 2.01 & $0.670 \pm 0.05$ & $0.670 \pm 0.028868$ \\
\hline T4-IC0631544 & 1.08 & 0.88 & 0.98 & 2.94 & $0.980 \pm 0.1$ & $0.980 \pm 0.057735$ \\
\hline T5-IC-0631546 & 0.95 & 0.7 & 0.9 & 2.55 & $0.850 \pm 0.132288$ & $0.850 \pm 0.076376$ \\
\hline $\begin{array}{l}\text { C. esculenta var. esculenta } \\
\text { (Cultivar-Panchamukhi) }\end{array}$ & 1.63 & 2.13 & 2.13 & \multirow{2}{*}{5.89} & $1.96 \pm 0.288675$ & $1.96 \pm 0.166667$ \\
\hline
\end{tabular}

*CD $(5 \%)=0.31$

Table 5. Taro productivity data analysis from the field trial of the farmers from Borail Hills Range, India (May-November 2017).

\begin{tabular}{|c|c|c|c|c|c|c|}
\hline No of parent/treatment/ genotypes & R1 & R2 & R3 & Total & $\operatorname{Mean} \pm$ SD & Mean \pm SE \\
\hline T1-IC0631527 & 0.61 & 0.59 & 0.62 & 1.82 & $0.607 \pm 0.015275$ & $0.607 \pm 0.008819$ \\
\hline T2- IC0631529 & 0.67 & 0.78 & 0.95 & 2.4 & $0.80 \pm 0.141067$ & $0.80 \pm 0.081445$ \\
\hline T3-IC0631536 & 0.47 & 0.51 & 0.48 & 1.46 & $0.487 \pm 0.02082$ & $0.487 \pm 0.012019$ \\
\hline T4-IC0631544 & 0.5 & 0.54 & 0.55 & 1.59 & $0.530 \pm 0.026458$ & $0.530 \pm 0.015275$ \\
\hline T5-IC-0631546 & 0.89 & 0.64 & 0.59 & 2.12 & $0.707 \pm 0.160728$ & $0.707 \pm 0.092796$ \\
\hline $\begin{array}{l}\text { C. esculenta var. esculenta } \\
\text { (Cultivar-Panchamukhi) }\end{array}$ & 0.96 & 1.11 & 1.23 & 3.3 & $1.10 \pm 0.135277$ & $1.10 \pm 0.078102$ \\
\hline
\end{tabular}

(Cultivar-Panchamukhi)

$* \mathrm{CD}(5 \%)=0.20$

**R1, R2, R3-Replicationsof data of tuber productivity in kg/plant; SD-Standard Deviation; SE-Standard Error

\section{Farmer's training for Taro cultivation package of practice}

Three hundred ninety-two hill farmers from 44 villages belonging to different ethnic communities were trained on the comprehensive package of practice (i.e. Improved cultivation practice) for upland cultivation of Taro. The training programme was organised and long reached with the help of eight local Master Trainers from the Borail Hills Range area during the month of December 2018.

\section{Conclusion}

Selection of the superior edible $C$. esculenta variants based on nutraceutical properties can play an important role in the enhancement of Taro tuber production in the similar upland agro-climatic regions of North East India. So, collection, conservation and multiplication of such important Taro variants are necessary for the benefit of the people of the region. The new, improved agrotechnique/cultivation process was proved to be helpful for significantly enhanced tuber productivity in the sustainable hill agricultural system throughout North East India.

From the field trials data analysis, it is concluded that the upland Taro tuber productivity has significantly been enhanced after using improved upland Taro cultivation practices. Thus, by selling the surplus tubers and their products in the 
makeshift/weekly markets will help for adding to the farmer's household budget. Production and marketing of the commercial starch from tuber crops are used in adhesives, dextrins, food, sweeteners, ethyl alcohol, soaps and detergents, laundry, cosmetic, pharmaceuticals and biodegradable plastics etc. will also be helpful for the opening of new vistas for agro-based cottage industries for the economic wellbeing of the ethnic people of North East India.

\section{Acknowledgements}

The authors express their heartfelt thanks to the ethnic people of Borail Hills Range of India for sharing their knowledge on edible aroids. The authors are also thankful to the Natural Resource Data Management System, Department of Science and Technology, Government of India to provide the necessary funds to carry out the present research work.

\section{Authors' contributions}

PM carried out the Taro germplasm collection, taxonomic identification, phytochemical analysis, improved upland Taro cultivation practice for productivity enhancement at ICAR-NBPGR, Umiam as well as Borail Hills Range, and also farmers' training for capacity building. AS contributed to the phytochemical analysis. HGD assisted in getting Indigenous Collection (IC) numbers, field trial at ICAR-NBPGR, Umiam for upland Taro tuber productivity evaluation and also farmers' training for capacity building.

\section{Conflict of interests}

Authors do not have any conflict of interests to declare.

\section{References}

1. Peter KV. Tuber Crops. National Book Trust, New Delhi, India; 2008. pp. 59-76.

2. Medhi P, Borthakur SK. Genetic resources of root and tuber crops from north Cachar hills of Assam. J Root Crops. 2011; 37 (2):131-43.

3. CTCRI. Agro-techniques of Tuber Crops. Ravindran CS, Ramanathan S, Eswaran M (Eds). Central Tuber Crops Research Institute (CTCRI), Thiruvananthapuram, India; 2013. pp. 1-32.

4. Purseglove JW. Araceae-Tropical Crops: Monocotyledons 1. Longman Group Ltd., London; 1972. pp. 58-74.

5. Wang JK. Taro: A Review of Colocasia esculenta and its Potential. Honululu: University of Hawaii;1983.

6. Jianchu X, Yongping Y, Yingdong P, Ayad WG, Eyzaguirre PB. Genetic diversity in Taro (Colocasia esculenta Schott, Araceae) in China: an ethnobotanical and genetic approach. Econ Bot. 2001;55:14-31.

7. Kreike CM, Van Eck HJ, Lebot V. Genetic diversity of Taro, Colocasia esculenta (L.) Schott, in Southeast Asia and the $\mathrm{Pa}$ cific. Theor Appl Genet. 2004;9:761-68.

8. Coursey DG. The edible Aroids. World crops. 1967;20(4):25-30.

9. Matthews PJ. Taro in Hawaii: present status and current re- search. Pl Genet Resour Newsltr. 1998;116:26-29.

10. Kumar Sudhir, Rajeswari S. Indigenous Agriculture and Germplasm conservation in North-Eastern Region: A Review. In: S. K. Jain (ed). Ethnobiology in Human Welfare (EHW). New Delhi: Deep Publ.;1996. p.315-17.

11. Medhi P, Borthakur SK. Phytoresources from North Cachar hills of Assam-III: Edible plants sold at Haflong market. Ind J Nat Prod Resour. 2012; 3(1):84-109.

12. Wilson JE. Agro Facts, Taro breeding, IRETA Publication No: 3/89; 1990.

13. CTCRI. Technologies for better crops-yam bean, coleus, arrowroot, colocasia (Dasheen) and xanthosoma, Central Tuber Crops Research Institute (CTCRI), Thiruvananthapuram, Kerala; 1996. p.18-21.

14. Tuia VS. In vitro multiplication of Taro (Colocasia esculenta var. esculenta (L.) Schott), M. Agri.: University of the South Pacific; 1997.

15. Taro Gen. Samoa Taro Breeding [Electronic Version]. 1999. Progress Report from http://users.bigpond.net.au/grahame/ Samoa.html

16. Singh D, Hunter D, Okpul T, Iosefa T. Introduction to techniques and methods of Taro breeding. AUSAID/SPC Taro Genetic Resources; 2001.

17. ICAR. Inventory of Indigenous Technological Knowledge in Agriculture. Document 1 . Indian Council of Agricultural Research, New Delhi 110 012, India. 2002; pp. 411.

18. Trujillo EE, Menezes TD, Cavaletto CG, Shimabuku R, Fukuda SK. Promising new Taro cultivars with resistance to Taro leaf blight: Pa'lehua, Pa'akala, and Pauakea, new plants for Hawaii. University of Hawaii: Cooperative Extension Services, College of Tropical Agriculture and Human Resources. 2002; pp. 1-4.

19. ICAR. Inventory of Indigenous Technological Knowledge in Agriculture. Document 2. Indian Council of Agricultural Research, New Delhi, India. 2003; pp.680.

20. Verma VM, Cho JJ, Aikne J, David J. High frequency plant production of Taro (Colocasia esculenta (L.) Schott) by tissue culture. Paper presented In: Proceedings for the 4th International Crop Science Congress, Brisbane, Australia; 2004.

21. Shaw DE. Illustrated notes on flowering, flowers, seed and ger mination in Taro (Colocasia esculenta). Research Bulletin: Department of Agriculture Stock and Fisheries, Port Morseby, Papua New Guinea. 1975; 13: 39-59.

22. Strauss MS, Michaud JD, Arditti J. Seed storage and germination and seedling proliferation in Taro (Colocasia esculenta (L.) Schott). Ann Bot. 1979;43:603-12.

23. Lambert M. Taro cultivation in the South Pacific. Noumea, New Caledonia: South Pacific Commission; 1982.

24. Jennings DL. Starch crops. In: Christie BR. (Ed). CRC Handbook of Plant Science in Agriculture. Vol. II. Boca Raton, Florida, USA. CRC Press, Inc.; 1987. pp.137-43.

25. Onwueme IC, Charls WD. Tropical root and tuber crops -production, perspective and future prospects, FAO production and protection paper 126, Rome; 1994. pp.139-61.

26. O"Sullivan JN, Asher CJ, Blamey FPC. Nutritional disorders of Taro. Australian Centre for International Agricultural Research, Canberra, Australia;1996.

27. Onwueme IC. Taro cultivation in Asia and Pacific. (FAO-RAP Publication No. 1999/16); 1999.

28. United States Department of Agriculture (USDA). Crop profile for Taro in American Samoa. Washington, DC: National Agricultural Statistics Service; 2001.

29. SPC. Taro research benefits small-holder, subsistance and commercial growers. [Electronic Version]. 2002. from http:// www.spc.org.nc/artTaro.html

30. Tyagi AP, Taylor M, Deo PC. Seed germination and seedling development in Taro (Colocasia esculenta). The South Pacific J Nat Sc. 2004; 22:61-65.

31. Opara LU. Edible aroids: post harvest operations. AGST/FAO; 2001. 
32. CTCRI. All India Co-ordinated Research Project on Tuber CropsAnnual Report 2001-02. Central Tuber Crops Research Institute (CTCRI), Thiruvananthapuram, Kerala;2002. pp.1-7.

33. FAO. Production Year Book for 1997. Food and Agriculture Organization of the United Nations, Rome, Italy; 1998

34. Mahajan RK, Sapra RL, Srivastava U, Sing M, Sarma GD. Minimal descriptors (for characterization and evaluation) of agri-horticultural crops (part-I). National Bureau of Plant Genetic Resources (NBPGR), New Delhi, India; 2000.

35. Hedge JE, Hofreiter BT. Carbohydrate Chemistry. 17th ed, New York: Academic Press; 1962.

36. Lowry OH, Rosebrough NJ, Farr AL, Randall RJ. Protein measurement with the folin phenol reagent. J Biol Chem. 1951;193:265-75.

37. Maynard AJ. Methods in Food Analysis: Physical, Chemical and Instrumental Methods of Analysis. 2nd ed. San Francisco, London: Academic Press; 1970. p.845.

38. Singleton VL, Rossi JAJ. Colorimetry of total phenolics with phosphomolybdic-Phosphotungstic acid reagents. Am J Enol Viticulture. 1965;16:144-58.

39. Khalaf NA, ShakyaAK, Al-OthmanA, El-Agbar Z, Farah H. Antioxidant activity of some common plants. Turk J Biol. 2008;32:51-55.

40. Sadasivam S, Theymoli B. Practical Manual in Biochemistry. Coimbatore, India: Tamil Nadu Agricultural University; 1987. p.14.

41. Kumar S, Kumar D, Manjusha, Saroha K, Singh N, Vashishta B. Antioxidant and free radical scavenging potential of Citrullus colocynthis (L.) Schrad. methanolic fruit extract; Acta Pharm 2008;58(2):215-20.

42. Latta M, Eskin M. A simple and rapid colorimetric method for phytate determination. J Agric Food Chem. 1980; 28(6):1313-15 https://doi.org/10.1021/jf60232a049

43. Jackson ML. Soil Chemical Analysis. Englewood Cliffs, New Jersey: Prentice Hall; 1958; p.498.

44. Brooks RR. Biological Methods of Prospecting for Minerals. New York: John Wiley \& Sons; 1986. p.313.

\section{Additional information}

Peer review information: Plant Science Today thanks Sectional Editor and the other anonymous reviewers for their contribution to the peer review of this work.

Reprints and permissions information is available at https://horizonepublishing.com/journals/index.php/PST/open_access_policy

Publisher's Note: Horizon e-Publishing Group remains neutral with regard to jurisdictional claims in published maps and institutional affiliations.

To cite this article: Medhi P, Sarma A, Harish G D. Comparative evaluation of traditional and improved cultivation practices and cultivars of Colocasia esculenta (L.) Schott in the Borail Hills Range of India. Plant Science Today. 2021;8(4):1057-1063. https://doi.org/10.14719/pst.2021.8.4.1154

Plant Science Today, published by Horizon e-Publishing Group, is covered by Scopus, Web of Science, BIOSIS Previews, Clarivate Analytics, etc. See https://horizonepublishing.com/journals/index.php/PST/indexing_abstracting 